\title{
Larval morphology, development and forensic importance of Synthesiomyia nudiseta (Diptera: Muscidae) in Europe: a rare species or just overlooked?
}

\author{
Y. Velásquez ${ }^{1 *}$, T. Ivorra ${ }^{1}$, A. Grzywacz ${ }^{2}$, \\ A. Martínez-Sánchez ${ }^{1}$, C. Magaña ${ }^{3}$, A. García-Rojo ${ }^{4}$ \\ and S. Rojo ${ }^{1}$ \\ ${ }^{1}$ University Research Institute of Biodiversity CIBIO, Department of \\ Environmental Sciences, University of Alicante, E-03080 Alicante, Spain: \\ ${ }^{2}$ Department of Animal Ecology, Institute of Ecology and Environmental \\ Protection, Nicolaus Copernicus University, 87-100 Toruń, Poland: \\ ${ }^{3}$ Anthropology Laboratory, Anatomical Forensic Institute, E-28071 Madrid, \\ Spain: ${ }^{4}$ Forensic Anthropology Laboratory, General Commissariat of the \\ Scientific Police, E-28043 Madrid, Spain
}

\begin{abstract}
The muscid Synthesiomyia nudiseta (van der Wulp, 1883) is a species with forensic importance in tropical and subtropical regions of the world. This fly has recently been introduced into southern Europe and, until now, had not been recorded in forensic cases in this region. Here, morphology of all larval instars of S. nudiseta is documented in detail by using a combination of light and scanning electron microscopy. Literature data concerning larval morphology are revised and characters allowing identification from other forensically important Muscidae are listed. The life cycle of this species was studied at four constant temperatures: $15,20,25$ and $30^{\circ} \mathrm{C}$. Total development varied between $46.50 \pm 0.97$ days at $15^{\circ} \mathrm{C}$ and $15.39 \pm 0.32$ days at $30^{\circ} \mathrm{C}$. Moreover, we report this species breeding in human corpses, for the first time in Europe, in forensic cases from autopsies at the Anatomical Forensic Institute of Madrid and the Institute of Legal Medicine of Alicante, Spain.
\end{abstract}

Keywords: Synthesiomyia nudiseta, larval morphology, scanning electron microscopy, preimaginal development, forensic entomology, postmortem interval, Europe

(Accepted 27 June 2012; First published online 29 August 2012)

\section{Introduction}

The muscid Synthesiomyia nudiseta (van der Wulp, 1883) is widespread in Old and New World tropics and subtropics, with $20^{\circ} \mathrm{C}$ annual isotherms (Skidmore, 1985). This species has

*Author for correspondence

Fax: + 34- 965903815

E-mail: yv@alu.ua.es, yelitza.velasquez@gmail.com been involved in forensic investigations in different countries, such as Costa Rica, India, Malaysia, Thailand and the United States (i.e. southern USA and Hawaii) (Jirón et al., 1983; Lord et al., 1992; Omar et al., 1994; Kulshrestha et al., 1997; Goff, 2000; Lee et al., 2004; Sukontason et al., 2007; Kumara et al., 2009). It has also been associated with human cadavers in archaeological contexts in Mexico and Peru (Huchet \& Greenberg, 2010).

In Europe, $S$. nudiseta has been recorded mainly from insular territories, such as Malta, the Azores, Madeira, 
the Canary Islands and two small islands close to the coast of Alicante (SE Spain) (Pont, 1986; Ebejer \& Gatt, 1999; Martínez-Sánchez et al., 2005). This species was recorded for the first time on the European mainland in 1996 from Marbella (Bowden, 1997), a locality situated on the coast of southern Spain, about $70 \mathrm{~km}$ from North Africa $\left(36^{\circ} \mathrm{N} 4^{\circ} \mathrm{W}\right)$. Until now, the distribution of $S$. nudiseta seemed to be restricted to insular territories and Mediterranean coastal areas because it has not been cited previously in studies about sarcosaprophagous dipteran communities in the interior of the peninsula.

This is the only known species under the genus Synthesiomyia Brauer \& Bergenstamm, 1893 (Muscidae: Azeliinae: Reinwardtiini). The larvae are commonly found in animal and human faeces, as well as in decaying vegetable matter and garbage. However, it has been reported that this species prefers carrion as the food source of its choice and will successfully pupate in confined environments (Byrd \& Castner, 2010; Byrd \& Tomberlin, 2010). Facultative carnivorous larvae feed just below the surface of the flesh and, often, post-feeding larvae secrete a silky white substance in which the puparium forms, frequently with adhered debris (Siddons \& Roy, 1942). This species is considered eusynanthropic because adults present a marked preference for human environments (Nazni et al., 2007; Uribe-M. et al., 2010) and are frequently associated with corpses discovered indoors at urban locations (Goff, 2000; Lee et al., 2004; Sukontason et al., 2007). Developmental studies of S. nudiseta are limited, and they have been performed in South America and Asia at 20, 26 and $28^{\circ} \mathrm{C}$ (Siddons \& Roy, 1942; Rabinovich, 1970; Krüger et al., 2002; Kumara et al., 2009).

Preimaginal stages have been described in several papers (Siddons \& Roy, 1942; Skidmore, 1985; Pires de Alencar \& Rios, 1992; Calderón-Arguedas et al., 2005; Sukontason et al., 2007; Ubero-Pascal et al., 2010b), and identification keys to mature larvae of this species can be found in Ishijima (1967), Skidmore (1985) and Velásquez et al. (2010). Although methods of scanning electron microscopy (SEM) have been used in some studies (Pires de Alencar \& Rios, 1992; El-Alfy, 1994; Ubero-Pascal et al., 2010a,b), no exhaustive documentation of larval morphology has been published until now.

Due to the potential usefulness of $S$. nudiseta in forensic investigations in southwestern Europe, the aims of this paper are (i) to describe details of larval morphology for all instars using combined methods of light microscopy and SEM, (ii) to provide development data of this species under four constant temperatures, and (iii) to review the cases where $S$. nudiseta has appeared breeding in human corpses in Spain.

\section{Materials and methods}

\section{Colony of Synthesiomyia nudiseta}

Larvae were collected from a human corpse during autopsy procedures at the Institute of Legal Medicine of Alicante (IMLA, Spain) and reared on pork liver ad libitum until development was completed. A colony was established at the Department of Environmental Sciences and Natural Resources, University of Alicante from emerged adults. The colony was maintained at $23^{\circ} \mathrm{C}, 60-70 \% \mathrm{RH}$ with a photoperiod of 12:12 (L:D) in mesh cages $(40 \times 40 \times 40 \mathrm{~cm})$ with sugar and water. Fresh fish was used for oviposition and pork liver as a food source for larvae.

\section{Larval morphology study}

Larvae for morphological study were obtained from the colony. They were killed by soaking in hot water $\left(\approx 97^{\circ} \mathrm{C}\right)$, cleaned with a fine brush and preserved in $70 \%$ ethanol. For light microscopy study, larvae were slide-mounted in Hoyer's medium using concave slides. Photographs were taken with a Nikon 8400 digital camera mounted on a Nikon Eclipse E200 microscope (Nikon Corp., Tokyo, Japan). For additional observations, larvae were prepared with methyl salicylate according to Niederegger et al. (2011). Preparation for SEM study involved dehydration through $80 \%, 90 \%$ and $99.5 \%$ ethanol, critical point drying in $\mathrm{CO}_{2}$, mounting on aluminium stubs with double-sided tape and coating with platinum. Images were taken with variable-pressure SEM (LEO 1455). Larval terminology follows Skidmore (1985) and Courtney et al. (2000) with a few modifications proposed by Szpila \& Pape (2005).

\section{Development under constant temperatures}

Growth and developmental time were evaluated under four constant temperatures $\left(15^{\circ} \mathrm{C}, 20^{\circ} \mathrm{C}, 25^{\circ} \mathrm{C}, 30^{\circ} \mathrm{C}\right)$, with $60-70 \% \mathrm{RH}$ and a photoperiod of 12:12 (L:D). After oviposition, egg masses $( \pm 12 \mathrm{~h}$ old $)$ were introduced into an environmental chamber at one of the four temperatures proposed. These eggs were checked every $12 \mathrm{~h}$ until larvae hatched. Then, 150 larvae were placed in a pot with $50 \mathrm{~g}$ of pork liver covered with mesh. For each temperature, ten replicates were carried out. Five of the largest larvae were collected daily, killed by soaking in hot water $\left(\approx 97^{\circ} \mathrm{C}\right)$ for five minutes and preserved in $70 \%$ ethanol. As a preliminary trial, five replicates at $12^{\circ} \mathrm{C}$ were performed. In this case, eggs were incubated at $25^{\circ} \mathrm{C}$ and then larvae were introduced into the environmental chamber at $12^{\circ} \mathrm{C}$. Larvae were collected every $24 \mathrm{~h}$ until the sixth day and after that, every $72 \mathrm{~h}$ until pupation.

To build growth curves, total length was measured using a digital vernier $(0.01 \mathrm{~mm})$ and the mean of the maximum length of larvae measured daily was plotted against time for each temperature regime. The minimal developmental time for larval and pupal stages was determined when the first five individuals in each replicate had changed to the next stage and it was recorded as the average of all pots. At $12^{\circ} \mathrm{C}$, only the larval stage was analyzed. For practical use in forensic investigation, developmental times from oviposition to adult emergence were represented against temperature in the isomorphen-diagram, where lines represent morphological changes and areas between lines represent identical morphological stages. Normality and homogeneity of variance of data were tested. A Kruskal-Wallis test $(\mathrm{H})$ was carried out to compare development between temperatures. If significant differences were found, post hoc pairwise comparison procedures were carried out using Dunn's method (SigmaStat for Windows 3.5).

Accumulated degree-days (ADD) for larval and total development at all studied temperatures were calculated from the formula: $\mathrm{ADD}=y\left(t-t_{0}\right)$, where $y$ is the developmental time in days, $t$ is the rearing temperature and $t_{0}$ is the minimum development threshold temperature. The $t_{0}$ was estimated from the linear regression of the development rate (developmental time ${ }^{-1}$ ) on constant temperature. 

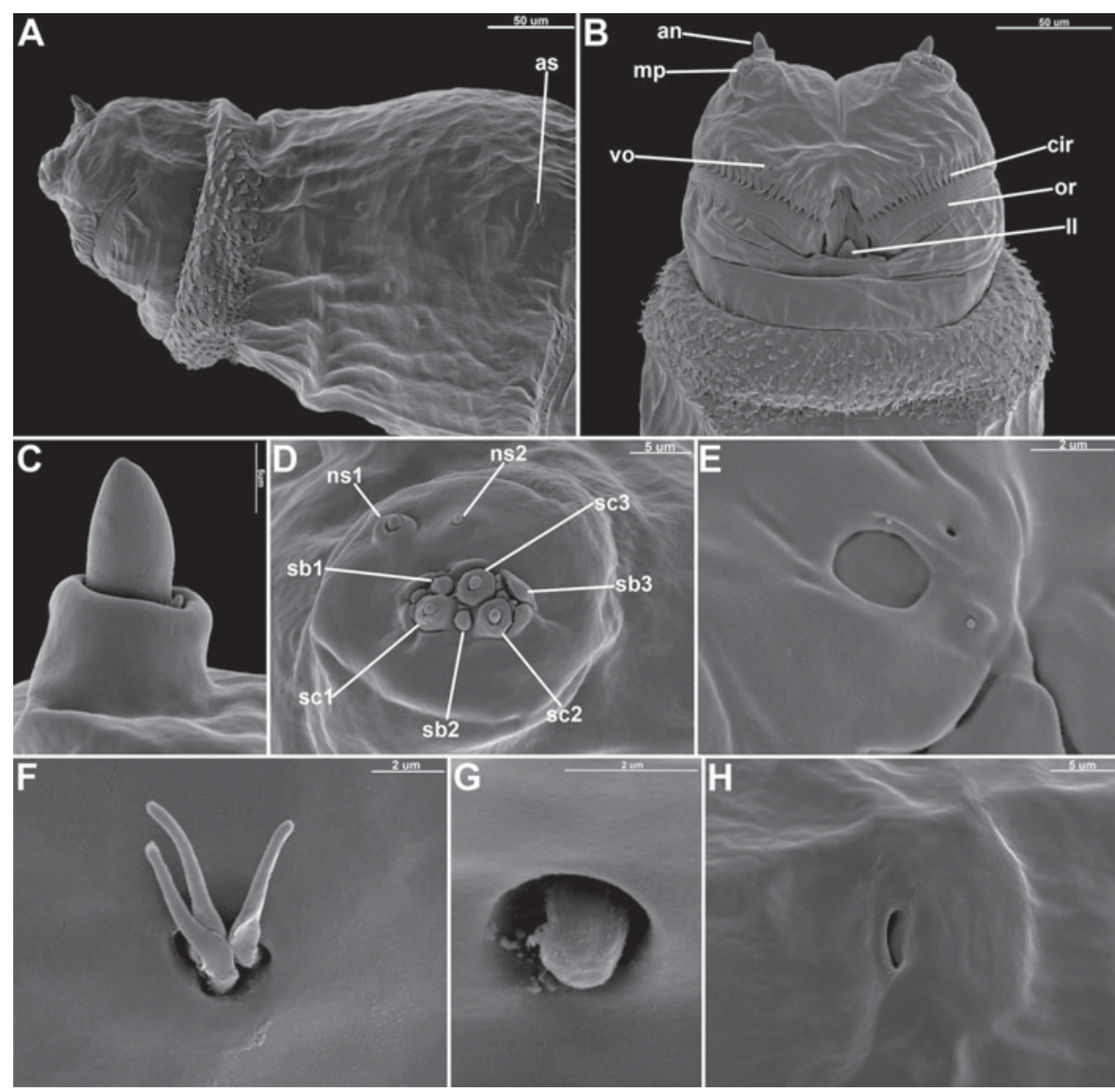

Fig. 1. First instar of S.nudiseta. (A) Anterior end of body, lateral view; (B) anterior end of body, ventral view; (C) antennal complex; (D) maxillary palpus; (E) ventral organ; (F) Keilin's organ; $(\mathrm{G})$ lateral sensillum; and (H) anterior spiracle. an, antennal complex; as, anterior spiracle; cir, cirri; ll, labial lobe; mp, maxillary palpus; ns1 [ns2], first [second] additional sensillum coeloconicum; or, oral ridges; sb1 [sb2/ sb3], first [second/third] sensillum basiconicum; sc1 [sc2/sc3], first [second/third] sensillum coeloconicum; vo, ventral organ.

\section{Analysis of forensic cases}

A review was conducted of the cases where $S$. nudiseta was involved, in autopsies carried out at the Anatomical Forensic Institute of Madrid (IAFM, Spain) and the IMLA. Fourteen cases were processed by the IAFM, one by the Forensic Anthropology Laboratory of the General Commissariat of the Scientific Police of Madrid and eight at the University of Alicante. One part of the larval sample was preserved, and the remainder of the larval and pupal samples were reared to the adult stage in an environmental chamber under controlled conditions $\left(23-25^{\circ} \mathrm{C}, 60-70 \% \mathrm{RH}\right)$. The larvae were reared with pork liver and pupae were kept individually. Specimens of $S$. nudiseta were identified using Skidmore (1985), Pont (1991) and Velásquez et al. (2010). Collected specimens were deposited in the Entomological Collection of the University of Alicante (CEUA).

\section{Results \\ Larval morphology}

\section{Pseudocephalon}

Each lobe of the bilobate pseudocephalon is equipped with an antenna, maxillary palpus, ventral organ and labial lobe (figs 1B-E; 2C-D and 3B-D). The antennal complex consists of an antennal dome situated on a basal ring (fig. 1C). The length of the antennal dome is similar to the height of the basal ring in the first instar and slightly shorter in the successive instars. The maxillary palpus in all instars consists of three sensilla coeloconica, three sensilla basiconica and one or more small additional sensilla, all in a tight cluster. Two typical sensilla coeloconica of possible non-maxillary origin are present laterodorsally on the surface of the maxillary palpus (figs $1 \mathrm{D}, 2 \mathrm{~B}$ and $3 \mathrm{C}$ ). In the second and third instars, maxillary palpus are surrounded by several rings of semicircular folds (figs 2B and 3C). A facial mask surrounding the functional mouth opening in the first instar is composed of cirri and oral ridges (fig. 1B). Cirri are arranged in one row and have a shape of stripes tapering distally, without distinct sclerotization (fig 4A, B). In the successive instars, oral ridges are more numerous, and sclerotized suprabuccal teeth are present in the anterior part of the buccal cavity (figs 2C, 3E, $4 \mathrm{C}-\mathrm{E}$ and $5 \mathrm{~B}, \mathrm{C})$. In the third instar, cutaneous teeth are present on the sides of the buccal cavity (figs $3 \mathrm{E}$ and $5 \mathrm{C}$ ).

\section{Cephaloskeleton}

The cephaloskeleton of the first instar (figs 4A, B and 5A) consists of paired mouthhooks, an unpaired labrum, an 

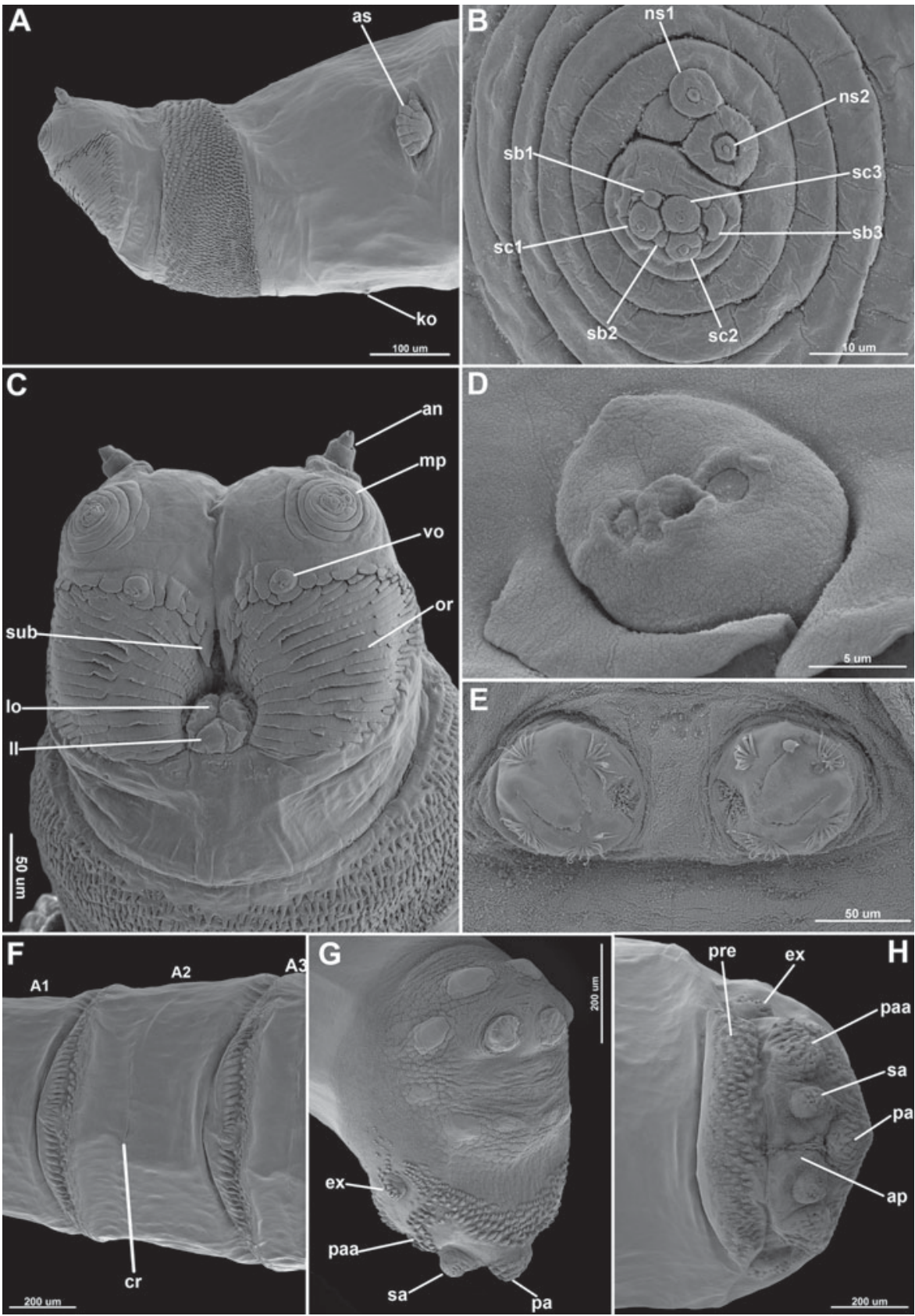

Fig. 2. Second instar of S. nudiseta. (A) Anterior end of body, lateral view; (B) maxillary palpus; (C) anterior end of body, ventral view; (D) ventral organ; (E) posterior spiracles; (F) abdominal segments, ventral view; (G) posterior end of body, latero-dorsal view; and (H) posterior end of body, ventral view. A1 [A2/A3], first [second/third] abdominal segment; an, antennal complex; ap, anal plate; as, anterior spiracle; cr, transverse crevice; ex, extra-anal papilla; ko, Keilin's organ; ll, labial lobe; lo, labial organ; mp, maxillary palpus; ns1 [ns2], first [second] additional sensillum coeloconicum; or, oral ridges; pa, postanal papilla; paa, para-anal papilla; pre, pre-anal papilla; sa, subanal pailla; sb1 [sb2/sb3], first [second/third] sensillum basiconicum; sc1 [sc2/sc3], first [second/third] sensillum coeloconicum; sub, suprabuccal teeth; vo, ventral organ.

unpaired intermediate sclerite and a basal sclerite with paired parastomal bars and paired vertical plates connected by a dorsal bridge, with ventral and dorsal cornua. The mouthhooks are shaped like a slightly up-curved rod, with a widened basal part. The mouthhooks are not equipped with teeth apically. The labrum is shaped like a knife blade with a broader basal part and narrower apical part and is fused with the tips of the parastomal bars. Each parastomal bar is long and, in the anterior part, equipped with a short process directed posteriorly. The $\mathrm{H}$-shaped intermediate sclerite is elongated, and the crossbeam is broad. The vertical plate is slightly broader than the width of the dorsal and 

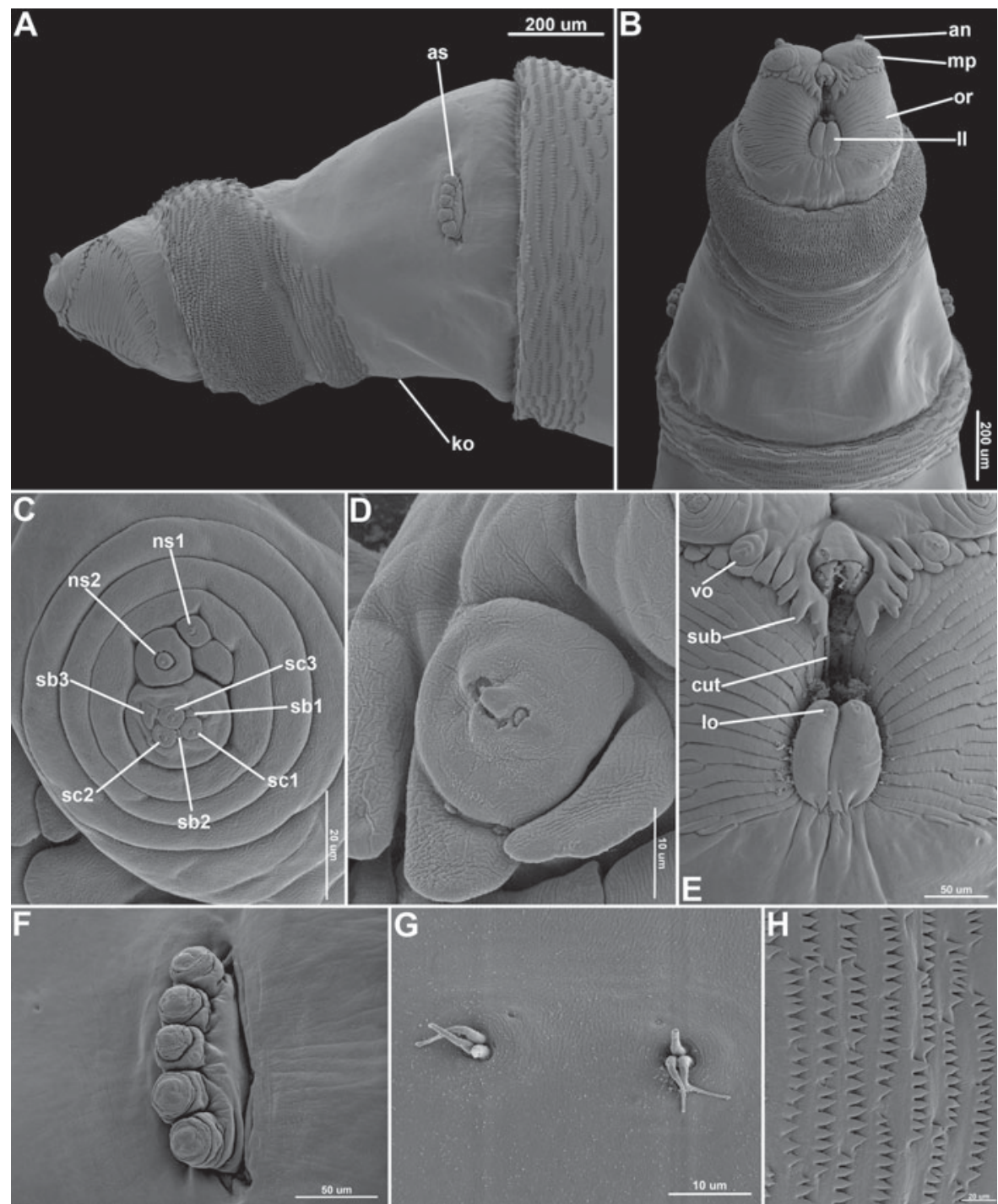

Fig. 3. Third instar of S. nudiseta. (A) Anterior end of body, lateral view; (B) anterior end of body, ventral view; (C) maxillary palpus; (D) ventral organ; (E) facial mask; (F) anterior spiracle; $(G)$ Keilin's organ; and (H) lateral spinulation of second thoracic segment. an, antennal complex; as, anterior spiracle; cut, cutaneous teeth; ko, Keilin's organ; 1l, labial lobe; lo, labial organ, mp, maxillary palpus; ns1 [ns2], first [second] additional sensillum coeloconicum; or, oral ridges; sb1 [sb2/sb3], first [second/third] sensillum basiconicum; sc1 [sc2/sc3], first [second/third] sensillum coeloconicum; sub, suprabuccal teeth; vo, ventral organ.

ventral cornua. The dorsal cornua are shorter than the ventral ones. The dorsal bridge has few perforations and is less sclerotized than the vertical plates and the ventral and dorsal cornua.

The cephaloskeleton of the second instar (figs 4C, D and $5 \mathrm{~B}$ ) consists of three main parts, paired mouthhooks, an unpaired intermediate sclerite and a basal sclerite. The mouthhooks are F-shaped with a robust basal part and slender distal part slightly curved ventrally. Paired suprabuccal teeth are present anteriorly to the mouthhooks; each consists of about three teeth. The suprabuccal teeth are not connected to the mouthhooks. Below the anterior ventrolateral extension of the mouthhooks, paired angular dental and paired toothlike accessory stomal sclerites are present. The intermediate sclerite is elongated, H-shaped with a broad crossbeam in lateral view directed anteroventrally. A longitudinal incision is present on the dorsal surface of the intermediate sclerite, forming a bar-like structure that does not reach the basal sclerite. Anterodorsally, an angular epistomal sclerite lies freely between the anterior arms of the intermediate sclerite, and a pair of labial sclerites lie anteroventrally. The epistomal sclerite is equipped with two rounded perforations. The dorsal bridge is well perforated. A necklace structure with two rounded perforations is present in the antero-ventral part of the vertical plate. Vertical plates are wider than the width of the dorsal and ventral cornua.

The cephaloskeleton of the third instar (figs $4 \mathrm{E}$ and 5C), as in the second instar, consists of three main parts and additional sclerites. Among the additional sclerites, paired oral bars with serrated tips and anterior ribbons adjoining 


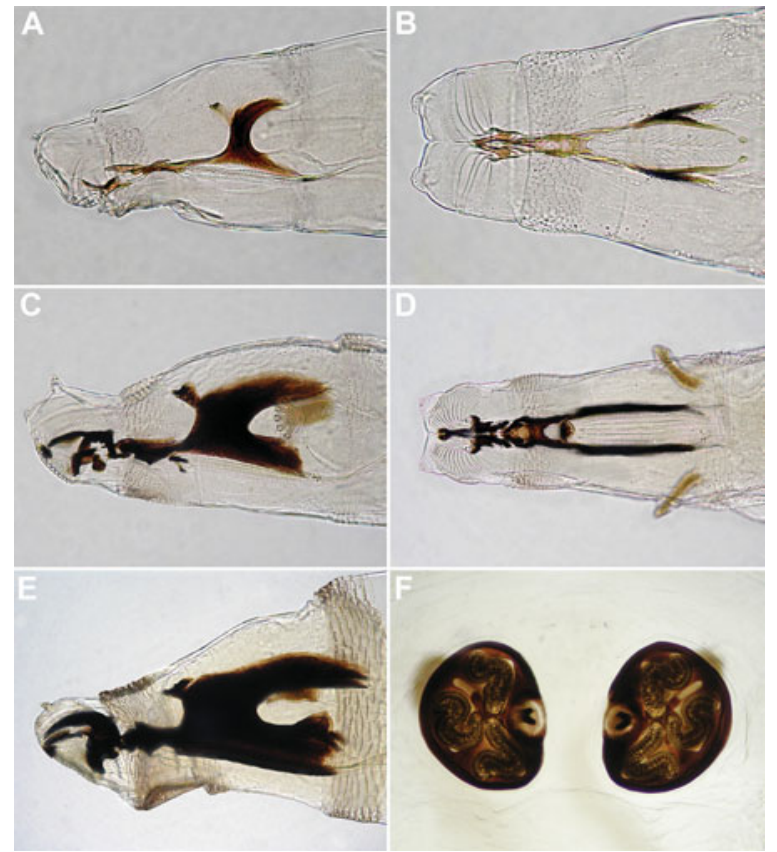

Fig. 4. Larvae of S. nudiseta. (A) First instar, cephaloskeleton, lateral view; (B) first instar, cephaloskeleton, ventral view; (C) second instar, cephaloskeleton, lateral view; (D) second instar, cephaloskeleton, ventral view; (E) third instar, cephaloskeleton, lateral view; and $(\mathrm{F})$ third instar, posterior spiracles.

dorsally, a pair of dental sclerites connected ventrally, paired accessory stomal sclerite, paired labial sclerite and an epistomal sclerite equipped with four rounded perforations are found. Posteriorly to the accessory stomal sclerites, a pair of supplementary accessory stomal sclerites is present in mature larva. Paired suprabuccal teeth, each consisting of about three teeth are not connected with mouthhooks. Between suprabuccal teeth and the dental sclerite, a row of cutaneous teeth is present on both sides of the buccal cavity. The dorsal bridge is finely perforated.

\section{Thoracic and abdominal segments}

Pair of trichoid sensilla of Keilin's organ are present on the ventral side of the thoracic segments (figs $1 F, 2 A$ and $3 A, G$ ). Anterior spiracles consist of four to six lobes (figs 2A, and 3A, $\mathrm{F})$, except for the first instar, where a simple aperture is present (fig. 1A, H). Openings of posterior spiracles are surrounded by four branched spiracular tufts (figs 2E, 6D and 7C). Slits of the posterior spiracles are straight in the first, slightly curved in the second and S-shaped in the third instar. The spiracular disc is surrounded by four pairs of papillae, located on the surface of the anal division in the first instar (fig. 6C, E) and on the small protuberances in the second (fig. 2G) and third (fig 7E, F) instars. The anal plate is triangular, relatively small and surrounded with well-developed papillae (figs $2 \mathrm{G}, \mathrm{H} ; 6 \mathrm{C}, \mathrm{F}$ and 7D-F). It is hardly visible in the lateral view (figs $2 \mathrm{G}$ and $6 \mathrm{E})$ and in the ventral view does not reach the base of para-anal papilla (figs $2 \mathrm{H}, 6 \mathrm{~F}$ and 7D). Subanal papillae of all instars are equipped with a small sensory papilla in the middle. Small sensilla coeloconica are present on thoracic and abdominal segments (fig. 1G). In the middle of the ventral surface of abdominal segments $1-7$, transverse crevice is present (figs $2 \mathrm{~F}$, $6 \mathrm{~A}, \mathrm{~B}$ and $7 \mathrm{~A}, \mathrm{~B}, \mathrm{D}$ ). Spinulation pattern (figs $2 \mathrm{~F}, 3 \mathrm{H}, 6 \mathrm{~A}, \mathrm{~B}$ and $7 \mathrm{~A}, \mathrm{~B}, \mathrm{D})$ found in our study are in accordance with the description by Siddons \& Roy (1942).

\section{Growth and duration of developmental stages}

Faster growth was observed when temperatures increased. Larval growth at all temperatures showed sigmoidal curves (fig. 8). The longest larvae always appeared the day before prepupa, at $25^{\circ} \mathrm{C}$ and $30^{\circ} \mathrm{C}$ on day 5 , at $20^{\circ} \mathrm{C}$ on day 6 , at $15^{\circ} \mathrm{C}$ on day 13 , and at $12^{\circ} \mathrm{C}$ on day 15 . After this, length decreased slightly when larvae entered the post-feeding stage and abandoned the food to pupate. The maximum length reached by the larvae showed significant differences between temperatures $(\mathrm{H}=93.40, \mathrm{df}=4, \mathrm{P}=<0.001)$. The largest larvae were obtained at $15^{\circ} \mathrm{C}(17.47 \pm 0.63 \mathrm{~mm})$ and the smallest at $12^{\circ} \mathrm{C}$ $(14.60 \pm 0.74 \mathrm{~mm})$. The largest individual was $19.34 \mathrm{~mm}$.

The duration of each developmental stage under all temperature regimes is presented in table 1 and illustrated in fig. 9. The increase of temperature had an effect on the duration of developmental stages, which decreased drastically. Total development varied between $46.50 \pm 0.97$ days at $15^{\circ} \mathrm{C}$ and $15.39 \pm 0.32$ days at $30^{\circ} \mathrm{C}$. There were significant differences in larval duration $(\mathrm{H}=162.41, \mathrm{df}=4, P<0.001)$, pupal duration $(\mathrm{H}=143.012, \mathrm{df}=3, P<0.001)$ and total development $(\mathrm{H}=143.019, \mathrm{df}=3, P<0.001)$. The rate of larval development increased with temperature $(y=0.0059 x-$ $\left.0.0179 ; \mathrm{R}^{2}=0.95\right)$. The $t_{0}$ was $3^{\circ} \mathrm{C}$ and degree-days varied between 154.00 and 183.96 DD. For total development, linear regression $\left(y=0.003 x-0.0219 ; \mathrm{R}^{2}=0.98\right)$ resulted in a $t_{0}$ of $7.3^{\circ} \mathrm{C}$ and degree-days ranged from 309.75 to $358.05 \mathrm{DD}$ (table 1).

\section{Analysis of the cases studied}

Table 2 shows a summary of the 22 cases, from the IAFM and IMLA, where $S$. nudiseta was present. Of these, 13 were found in the centre of the country (Madrid), eight in the southeast (Alicante) and one in the northwest (Ourense). A total of 17 cases were dated from autumn, two from spring, two from summer and one from winter. With the exception of one case, $S$. nudiseta was always present indoors, and most corpses were mummified to some degree. Larvae of $S$. nudiseta were collected from different regions of the corpses, including the natural openings of the head, torso, genitals and legs. In several cases, pupae and empty pupae were located attached to the clothes and hair (fig. 10A-C). Regarding succession, analyzed cases suggest that the arrival time of S. nudiseta could be different according to environmental conditions. It is the first colonizer in autumn but arrives after Calliphora vicina Robineau-Desvoidy, 1830 during colder months, whereas in summer it arrives together with, or after Chrysomya albiceps (Wiedemann, 1819), Lucilia sericata (Meigen, 1826) and Sarcophaga sp. Meigen, 1826. Next, a case from IMLA that has been considered the most representative of the usefulness of this species in southern Europe is presented.

\section{IMLA Case: 794/2010}

The fully clothed body of a woman was found sitting on the couch in an apartment in Torrevieja on 4 November 2010. The corpse was mummified. The body showed no signs of injury or criminal violence and death had been due to natural causes. 
A
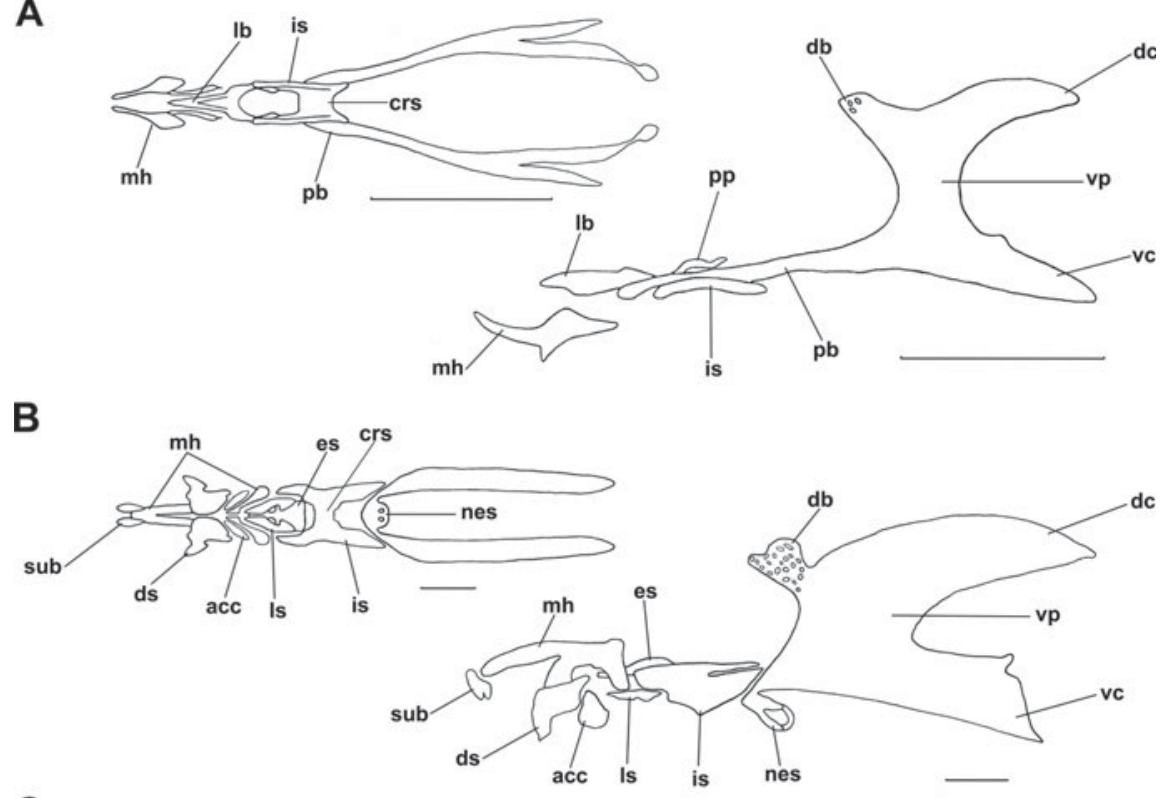

C

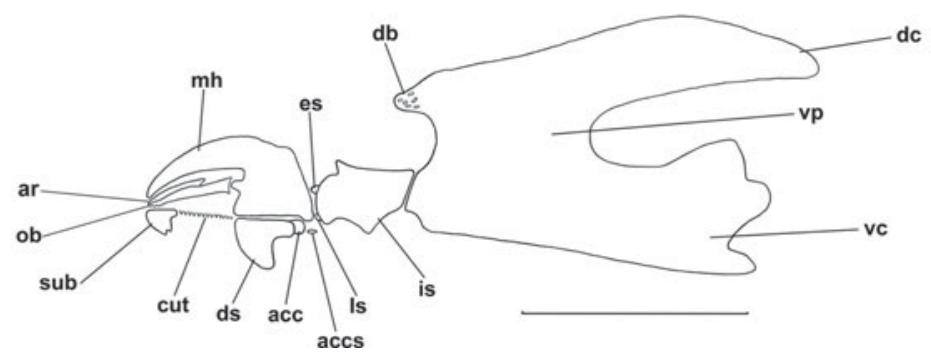

Fig. 5. Cephaloskeletons of S. nudiseta larvae. (A) First instar, ventral and lateral view; (B) second instar, ventral and lateral view; and (C) third instar, lateral view. acc, accessory stomal sclerite; accs, supplementary accessory stomal sclerite; ar, anterior ribbon, crs, crossbeam, cut, cutaneous teeth; db, dorsal bridge; dc, dorsal cornua; ds, dental sclerite; es, epistomal sclerite; is, intermediate sclerite; lb, labrum; ls, labial sclerite; $\mathrm{mh}$, mouthhooks; nes, necklace structure; ob, oral bar; pb, parastomal bar; pp, process diverging from the parastomal bar; sub, suprabuccal teeth; vc, ventral cornua; vp, vertical plate. Scale bare $0.1 \mathrm{~mm}(\mathrm{~A}, \mathrm{~B})$ and $1 \mathrm{~mm}(\mathrm{C})$.

The maximum postmortem interval $\left(\mathrm{PMI}_{\max }\right)$ (time of death) estimated by the pathologist was 40 days. The average temperature in the area, before the discovery of the body was $19.1^{\circ} \mathrm{C}$. The entomological samples were one pupa of C. vicina, larvae, pupae and empty puparia of $C h$. albiceps (Calliphoridae), larvae and pupae of $S$. nudiseta and pupae of Megaselia scalaris (Loew, 1866) (Phoridae).

The species collected with the most advanced developmental stage was $C h$. albiceps, with empty puparium; however, they were low in number and the majority of adults emerged two days later in the laboratory. In contrast, pupae of S. nudiseta were the most abundant sample; and, together with $M$. scalaris, they emerged three days after being collected. No adult emerged from the single pupa of $C$. vicina. According to several authors (Marchenko, 2001; Al-Misned et al., 2003; Grassberger et al., 2003), Ch. albiceps completes its cycle in approximately 19 days at $20^{\circ} \mathrm{C}$. Data from this study (table 1 , fig. 9) and results obtained by Rabinovich (1970) indicate that S. nudiseta needs about 26-27 days to complete its development at $20^{\circ} \mathrm{C}$. For M. scalaris, information on development at $20^{\circ} \mathrm{C}$ is highly variable, but pupae of this species have been found in corpses indoors with a PMI of 10-20 days (Disney, 2008). Given that S. nudiseta has the longest cycle, was more abundant and spent more time on the corpse, we can suppose that this species was the first colonizer. A minimum postmortem interval of around 24 days, based on S. nudiseta, was estimated.

\section{Discussion}

The updated distribution of S. nudiseta from European mainland includes littoral southeast Iberian Peninsula, from the provinces of Alicante (Martínez-Sánchez, 2003), Murcia (Ubero-Pascal et al., 2010b), Granada (J. Marín, personal communication) and Málaga (Bowden, 1997). Recently, this species has also been collected from Lisbon, Portugal (Prado e Castro et al., 2012) and Naples, Italy (Lebrun \& Mayer, 2011). After a review of forensic cases, we realized that the first appearance of $S$. nudiseta in a corpse was in 2004 in Madrid (central Spain). What is more, the record of Ourense (northwest Spain) confirms that this species has established itself in the Mediterranean Basin and is expanding its distribution 

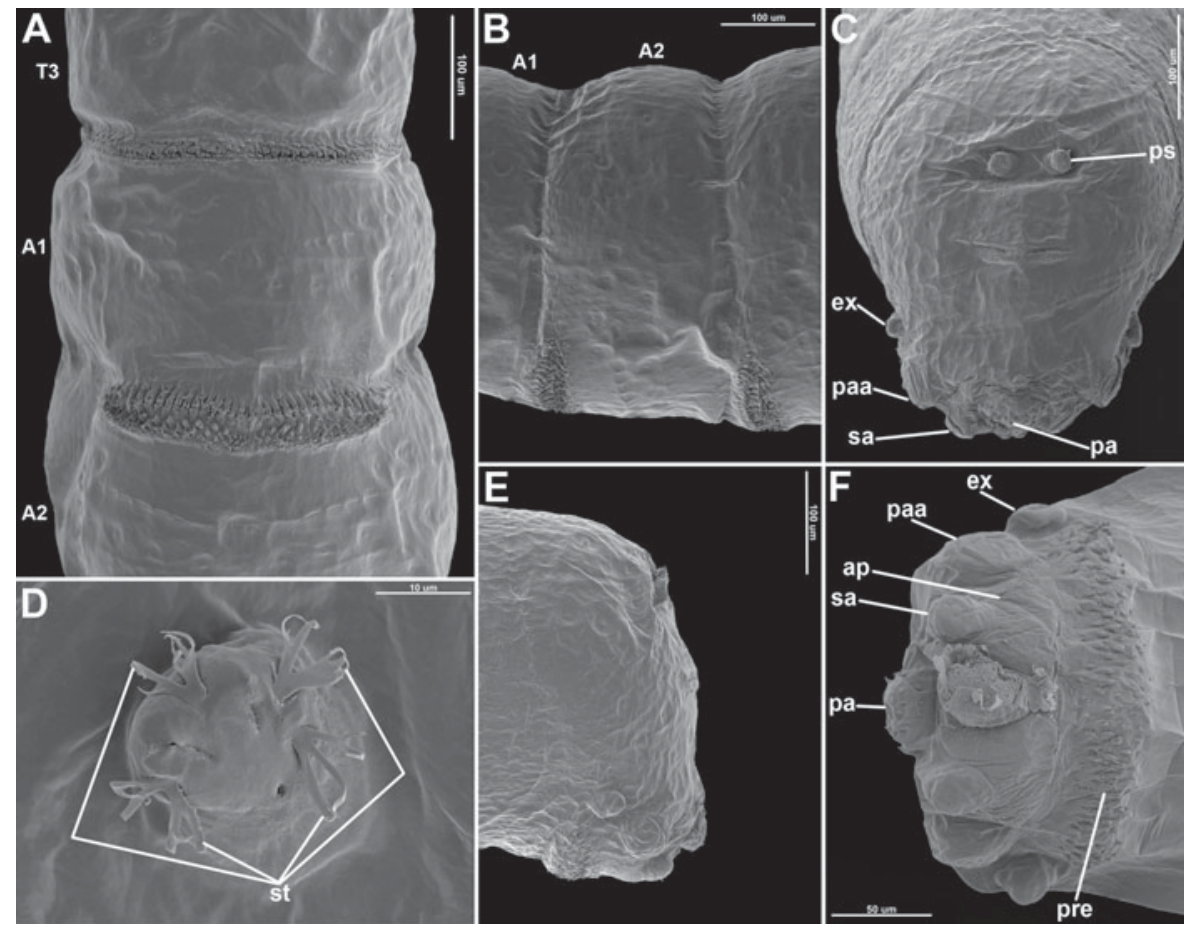

Fig. 6. First instar of S. nudiseta. (A) Thoracic and abdominal segments, ventral view; (B) abdominal segments, lateral view; (C) posterior end body, posterior view; (D) posterior spiracle; (E) posterior end of body, lateral view; and (F) posterior end of body, ventral view, A1 [A2], first [second] abdominal segment; ap, anal plate; ex, extra-anal papilla; pa, postanal papilla; paa, para-anal papilla; pre, pre-anal papilla; ps, posterior spiracle; sa, subanal pailla; st, spiracular tufts; T3, third thoracic segment.

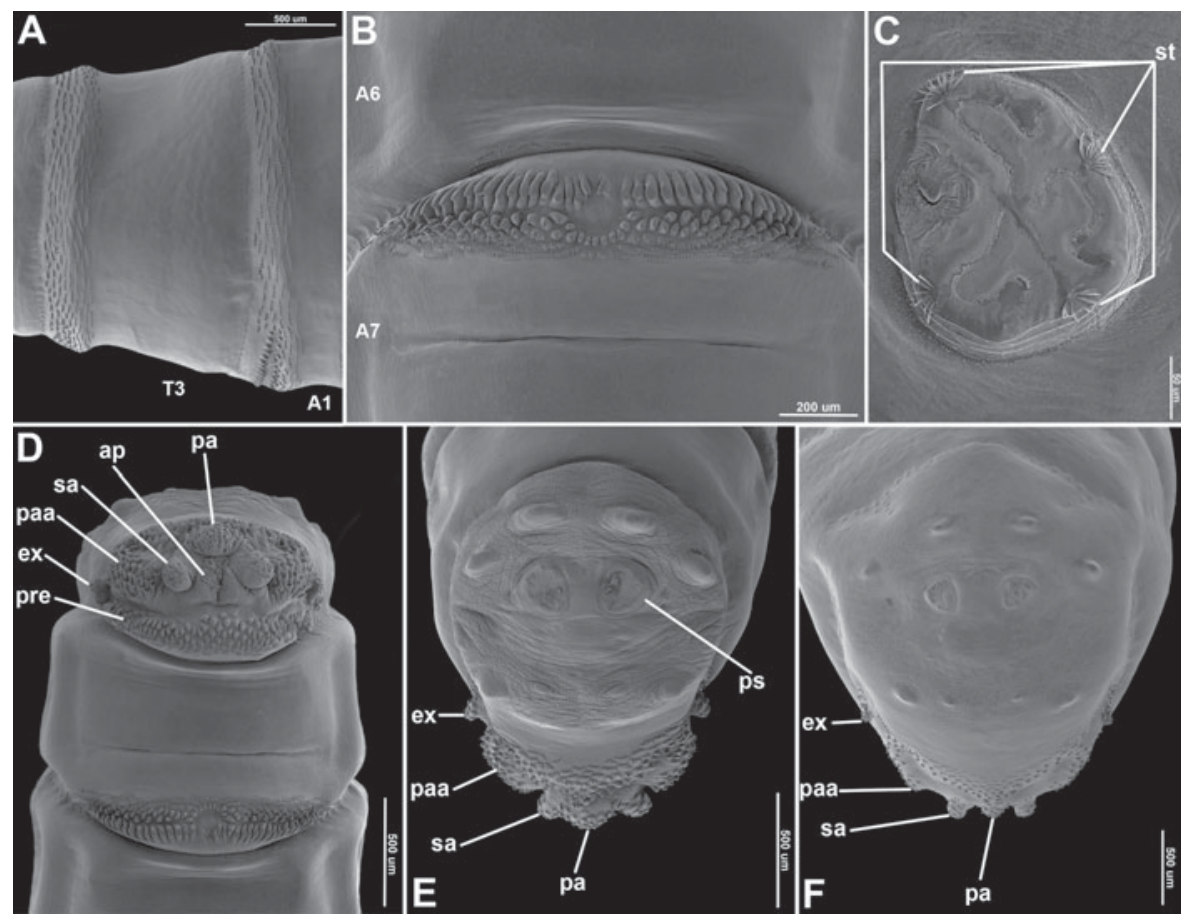

Fig. 7. Third instar of S. nudiseta. (A) Thoracic and abdominal segments, lateral view; (B) abdominal segments, ventral view; (C) posterior spiracle; (D) posterior end of body, ventral view; (E) posterior end of body of young larva, posterior view; and (F) posterior end of body of mature larva, ventral view. A1 [A6/A7], first [sixth/seventh] abdominal segment; ap, anal plate; ex, extra-anal papilla; pa, postanal papilla; paa, para-anal papilla; pre, pre-anal papilla; ps, posterior spiracle; sa, subanal pailla; st, spiracular tufts; T3, third thoracic segment. 
Table 1. Duration (mean \pm SD) of developmental stages and accumulated degree-days for S. nudiseta, for each temperature regime.

\begin{tabular}{lcccrr}
\hline Stage & \multicolumn{4}{c}{ Minimum duration (days) } \\
\cline { 2 - 6 } & $12^{\circ} \mathrm{C}$ & $15^{\circ} \mathrm{C}$ & $20^{\circ} \mathrm{C}$ & $25^{\circ} \mathrm{C}$ & $30^{\circ} \mathrm{C}$ \\
\hline Egg & - & $2.00 \pm 0.50$ & $1.00 \pm 0.50$ & $1.00 \pm 0.50$ & $0.50 \pm 0.50$ \\
Larva & $19.80 \pm 0.45^{\mathrm{a}}$ & $15.33 \pm 0.76^{\mathrm{a}}$ & $9.56 \pm 0.69^{\mathrm{b}}$ & $7.00 \pm 0.59^{\mathrm{c}}$ & $6.78 \pm 0.42^{\mathrm{c}}$ \\
Pupa & - & $28.87 \pm 0.35^{\mathrm{a}}$ & $15.73 \pm 0.89^{\mathrm{b}}$ & $9.73 \pm 0.45^{\mathrm{c}}$ & $17.50 \pm 0.78^{\mathrm{c}}$ \\
Egg to adult & - & $46.50 \pm 0.97^{\mathrm{a}}$ & $26.33 \pm 0.48^{\mathrm{b}}$ & $15.39 \pm 0.32^{\mathrm{d}}$ \\
ADD larval & 178.20 & 183.96 & 162.52 & 154.00 & 309.75 \\
ADD total & - & 358.05 & 334.39 & 349.35 \\
\hline
\end{tabular}

${ }^{\mathrm{abc}}$ Different letters within rows indicate significant differences $(P<0.05)$.

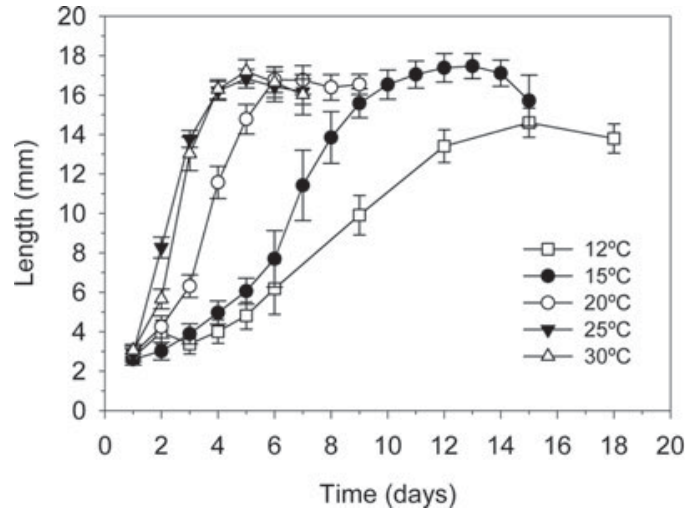

Fig. 8. The mean $( \pm \mathrm{SD})$ length of $S$. nudiseta larvae, measured at 24 - $h$ intervals for each temperature regime $(n=50)$. At $12^{\circ} \mathrm{C}$, after the sixth day larvae were measured every $72 \mathrm{~h}(n=25)$.

northwards. In addition, continuous sampling at the Campus of the University of Alicante shows that abundance of $S$. nudiseta has increased during the last years, frequently being observed in large numbers during warmer months from early summer onwards (Y. Velásquez, personal observation). This species should not be rare in human remains in other areas of southern Europe. Probably, this species has been overlooked previously because it does not appear in most available 'forensic' identification keys and, moreover, may have been confused with other Muscidae (wrongly identified as genus Muscina Robineau-Desvoidy, 1830 or Musca Linnaeus, 1758).

Separation of the larvae of $S$. nudiseta from other species of Muscidae that are also found during forensic entomology examinations is restricted because of limited information on larval morphology of these flies. The identification of the third instar larvae is relatively easy, thanks to the keys of Ishijima (1967), Skidmore (1985) and recently Velásquez et al. (2010). According to these authors, identification of the third instar is based on the presence of the suprabuccal teeth and cutaneous teeth (figs $3 \mathrm{E}$ and $5 \mathrm{C}$ ), as well as on the peculiar S-shaped slits of posterior spiracles (figs $4 \mathrm{~F}$ and $7 \mathrm{C}$ ) and dark pigmentation of the peritreme. Providing a key or any information allowing identification of the first and second instars is seriously limited. Tentatively, it could be stated that identification of the first instar of $S$. nudiseta is possible because of the presence of sharply ended cirri (fig. 1B), the smooth surface of the dorsal side of thoracic segments (fig. 1A) and a small triangular anal plate surrounded by well-developed papillae (fig. 6C, E, F).

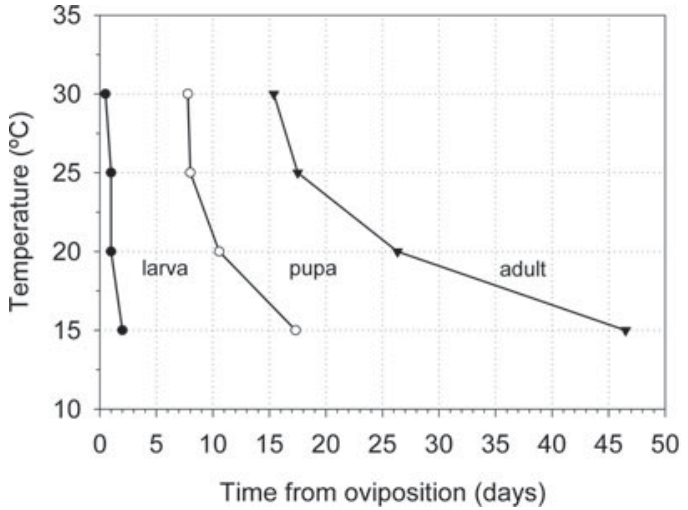

Fig. 9. Isomorphen-diagram for $S$. nudiseta, showing the duration of developmental stages from oviposition to eclosion, at 15, 20, 25 and $30^{\circ} \mathrm{C}$. $\bullet$, egg hatching; $\bigcirc$, pupation; $\boldsymbol{\nabla}$, adults emergence.

For the second instar, the most valuable characters are the small triangular anal plate surrounded by well-developed papillae (fig. 2G, H) and F-shaped mouthhooks (figs $4 \mathrm{C}$ and 5B) (Grzywacz et al., unpublished data). On the other hand, relatively easy identification of adults is possible based on the uniquely orange flagellomere and tip of abdomen (fig. 11A) together with wing vein $M_{1}$ curved forward towards vein $R_{4+5}$ (fig. 11B), not angular (fig. 11C), and lack of the orange or reddish tip of the scutellum (Pont, 1991; Carvalho, 2002; Couri, 2007).

Larval morphology of $S$. nudiseta was described by Siddons \& Roy (1942); we have focused here on characters insufficiently described or completely omitted. Results of our study agreed with their descriptions and most differences are due to the different terminology; however, a few contradictions were found, mainly in the cephaloskeleton structures. The parastomal bar of the first instar of S. nudiseta in Siddons \& Roy's (1942) fig. 5 is shown as simple and not connected with the basal sclerite. During this study, a process diverging from the parastomal bar was found, and parastomal bars are continuous with the basal sclerite (figs $4 \mathrm{~A}$ and $5 \mathrm{~A}$ ), as has been reported in other families (Courtney et al., 2000; Szpila \& Pape, 2005; Szpila et al., 2008b; Szpila, 2010; Szpila \& Villet, 2011). We clearly differentiate the epistomal and labial sclerites in the second and third instars, which Siddons \& Roy (1942) showed as an integral part of the intermediate sclerite, except for an imprecise outline on the drawing of the third instar in their fig. 15. 
Table 2. Summary of the cases from IAFM and IMLA where S. nudiseta appeared breeding in human corpses. Postmortem interval estimated by forensic pathologist or from witness testimonial of the last sighting of the individual alive.

\begin{tabular}{|c|c|c|c|c|c|}
\hline Year & Date of discovery & Place & Locality $^{1}$ & $\mathrm{PMI}_{\max }$ (days) & Samples collected \\
\hline \multirow[t]{2}{*}{2004} & September & Indoor & Madrid & 6 & LIII \\
\hline & October & Indoor & Madrid & 4 & LIII \\
\hline 2006 & May & Indoor & Madrid (Valdemoro) & 60 & $\mathrm{EP}$ \\
\hline \multirow[t]{4}{*}{2008} & September & Indoor & Madrid & 9 & LIII \\
\hline & September & Indoor & Ourense & 12 & $\mathrm{P}$ \\
\hline & October & Indoor & Madrid & 20 & $\mathrm{EP}$ \\
\hline & October & Indoor & Madrid & 18 & $\mathrm{P}$ \\
\hline 2009 & June & Indoor & Madrid & 14 & $\mathrm{EP}$ \\
\hline \multirow[t]{4}{*}{2010} & January & Indoor & Madrid & 60 & $\mathrm{EP}$ \\
\hline & January & Indoor & Alicante (Torrevieja) & $20-30$ & LI, LII, LIII \\
\hline & April & Outdoor & Alicante & $30-40$ & LIII, P, EP \\
\hline & June & Indoor & Alicante (San Vicente del Raspeig) & $7-10$ & LIII \\
\hline \multirow{4}{*}{2011} & October & Indoor & Madrid & 13 & $\mathrm{P}$ \\
\hline & October & Indoor & Madrid & 18 & LIII \\
\hline & October & Indoor & Alicante (Torrevieja) & 7 & $\mathrm{~L} ?$ \\
\hline & November & Indoor & Alicante (Benidorm) & $30-40$ & LIII, P, EP \\
\hline
\end{tabular}

1 Madrid (central Spain); Ourense (northwest Spain); Alicante (southeast Spain)

E, eggs; LI, larva of first; LII, second; LIII, third instar; P, pupa; EP, empty puparia; L?, larva of unknown instar.

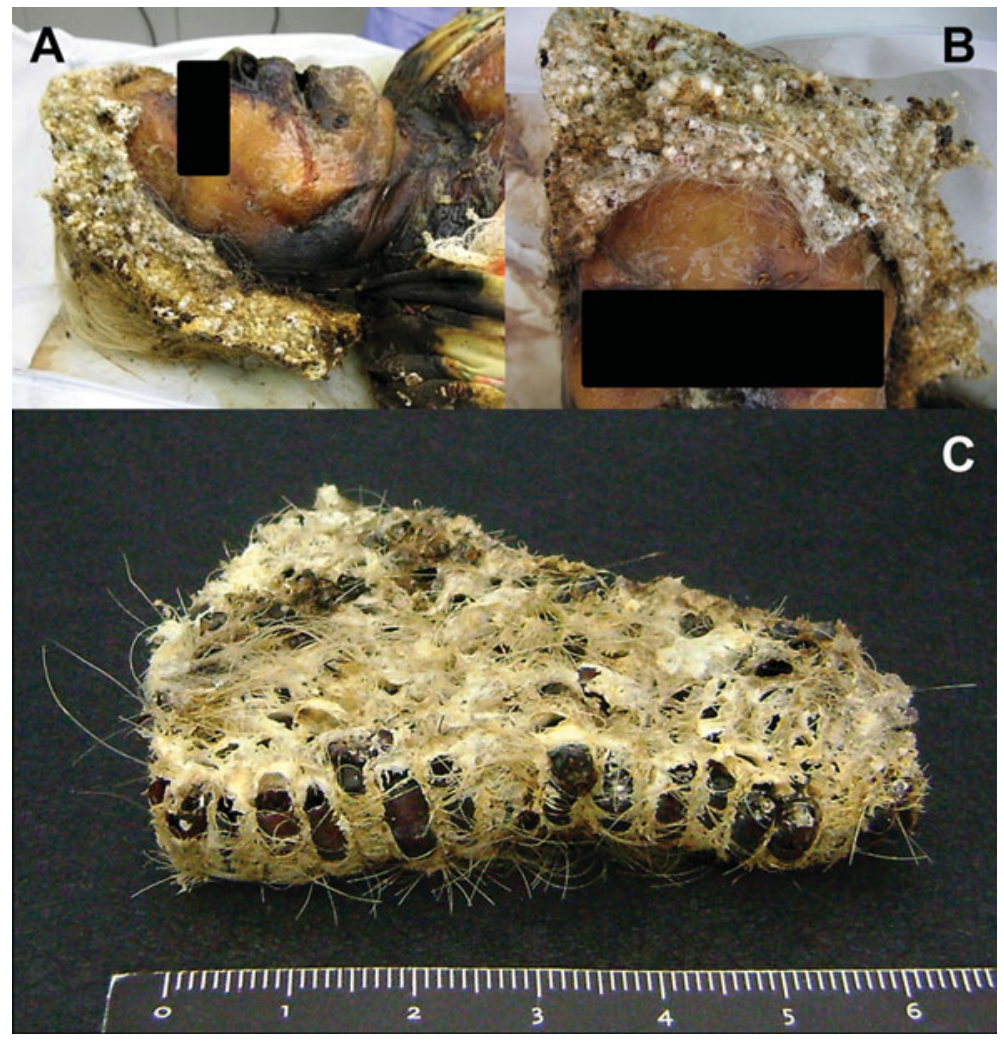

Fig. 10. Pupae of S. nudiseta embedded in the hair of the deceased. (A) Lateral and (B) frontal view, and (C) detail of the pupae. 
A

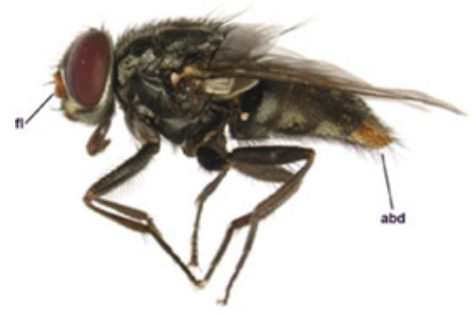

B

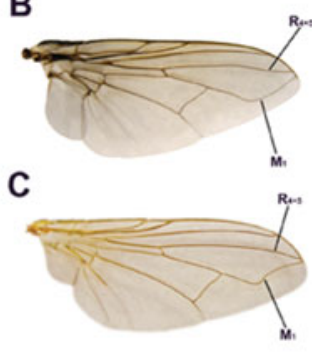

Fig. 11. (A) Adult female of $S$. nudiseta with orange flagellomere (fl) and tip of abdomen (abd); (B) wing of S. nudiseta, dorsal view; and (C) wing of Musca domestica, dorsal view. $\mathrm{M}_{1}, \mathrm{R}_{4+5}$, wing veins.

The cirri of the first instar were described by Siddons \& Roy (1942) as "the anterior margin of the first (oral) groove". Similarly to Siddons \& Roy (1942) and Skidmore (1985), we did not observe any presence of the suprabuccal teeth in the first instar although these structures have been found among first instars of other Muscidae, e.g. in Muscina (Skidmore, 1985), Philornis downsi Dodge \& Aitken, 1968 (Fessl et al., 2006) (as cuticular teeth) and Musca domestica (Linnaeus, 1758) (Skidmore, 1985; Szpila \& Pape, 2008). For S. nudiseta, there is no doubt that suprabuccal teeth, present in the second and third instars, are separate structures because there are no signs of any connection with mouthhooks. In other families, sclerotized structures present on the facial mask have been recognized unambiguously (Szpila \& Pape, 2005; Szpila et al., 2008b; Szpila, 2010; Szpila \& Villet, 2011) or with some reserves (Grzywacz et al., 2012) as integral parts of the mouthhooks.

Based on drawings of fig. 7 in Siddons \& Roy (1942), one could consider the presence of a parastomal bar in the second instar larva of S. nudiseta as Skidmore (1985) did. He has indicated the occurrence of a distinct parastomal bar (as a parastomal sclerite), but the presence of such a feature would be unusual and primitive because of the general absence of the parastomal bar in the second and third instars of Muscidae (Skidmore, 1985). According to our observations, a longitudinal incision is present on the dorsal surface of the lateral arms of intermediate sclerite, forming a bar-like feature that does not reach the basal sclerite (fig. 7B). In our opinion, Siddons \& Roy (1942) have wrongly recognized this bar-like feature as separated from the intermediate sclerite and connected with the basal sclerite, causing mistakes in Skidmore's interpretation of literature data.

Regarding development, information about the growth of this species is limited. According to the description of Skidmore (1985), the range of the length of the third instar is $7.0-19.5 \mathrm{~mm}$, similar to our findings. Compared with the study of Kumara et al. (2009), the maximum length of larvae at $28^{\circ} \mathrm{C}$ was $14.9 \mathrm{~mm}$, considerably lower than our values between 25 and $30^{\circ} \mathrm{C}$, but they measured five larvae randomly instead of the largest as in the current study. On the other hand, we observed an increase in developmental periods with lower temperatures. Our findings were similar to those reported by Rabinovich (1970) at $20^{\circ} \mathrm{C}$ and $28^{\circ} \mathrm{C}$, but higher than those found in Asia (Siddons \& Roy, 1942; Kumara et al., 2009) and slower than Krüger et al. (2002). Differences between development times may be due to different methods used in each study, e.g. the use of fluctuating temperatures (Siddons \& Roy, 1942; Kumara et al., 2009) or the use of a carbohydrate diet instead of a protein diet (Krüger et al., 2002). Moreover, it has been proposed that some species do not exhibit the same growth pattern in different geographical areas (Greenberg, 1991; Grassberger \& Reiter, 2001; Donovan et al., 2006; MartínezSánchez et al., 2007). In any case, generation of development data for local populations is imperative in order to permit the proper use of this species of tropical origin in forensic investigations in Europe.

Studies related to low temperatures for this species do not exist. Although in trials at $12^{\circ} \mathrm{C}$, eggs were reared at high temperatures $\left(23-25^{\circ} \mathrm{C}\right)$, larvae were successfully reared at $12^{\circ} \mathrm{C}$. We do not know what the development of S. nudiseta would be like at low temperatures in natural conditions in the Mediterranean region; but, the fact that adults have been captured in the field at $12^{\circ} \mathrm{C}$ (Martínez-Sánchez, 2003), larvae have been collected breeding in winter and a minimum development threshold estimated of $3^{\circ} \mathrm{C}$ and $7.3^{\circ} \mathrm{C}$ for larval and total development, respectively, suggest that this species of tropical origin could have adapted to the lower temperatures that occur in these latitudes in colder months.

The entomological evidence from reviewed cases suggests that the presence of $S$. nudiseta in human remains is strongly determined by ecological conditions, and its abundance and arrival time varied throughout the year. The high frequency of this species in cases dated from autumn and the heavy infestation observed in this season agree with a phenology study with wind oriented traps (WOT traps) performed in Alicante in 1997, in which this species was present throughout the year with the highest abundance in autumn (Martínez-Sánchez, 2003). Possibly the highest values of humidity produced by autumn rainfall favour the abundance and the arrival time of S. nudiseta. Apparently, this species is able to reach bodies not only inside buildings but also outdoors. Until now, it had not been reported in outdoor remains; nevertheless, in that case, the body was wrapped by a blanket, so it is possible that the wrapping creates a particular microhabitat that allowed oviposition and development of this species outdoors.

Abundance of S. nudiseta on the corpse can give us some conclusions about the season of death, because its activity is dependent on the warm and wet months. Nevertheless, it seems that the main forensic value of this species is the estimation of minimum time of death when the death occurs during autumn, when this species seem to be one of the first colonizers and is more abundant or, in those cases, when pioneer species do not have access to the body or their maggots migrate away from the remains.

The recent records of S. nudiseta from Spain, Portugal and Italy are evidence of range expansion of this species in southern Europe as occurred in the past with other forensically important flies such as Ch. albiceps (Grassberger et al., 2003; Verves, 2004; Gosselin \& Braet, 2008; Szpila et al., 2008a). Therefore, we should like to draw forensic entomologists' attention to the possible presence of this species in entomological material collected from experimental and real cases and its potential use as a forensic indicator.

\section{Acknowledgements}

We thank the authorities of the IAFM and IMLA, especially Dr Salvador Giner, for allowing us to collect entomological samples and his close cooperation during the analysis of 
the cases. We thank Dr Martin J.R. Hall for help during research on larval morphology at the Natural History Museum (London, UK). We are very grateful to Dr Henry Disney at the University of Cambridge for identification of Phoridae, to José Marín for his contribution to the update of the distribution of the species (http://www.diptera.info) and to the Spanish Meteorological Agency (AEMET) for providing weather data. We also thank two anonymous reviewers and Dr Jens Amendt at the Institute of Forensic Medicine, University of Frankfurt (Germany) for valuable comments on an earlier version of the manuscript. This work is part of a PhD project supported by the Programme Alßan, (European Union Programme of High Level Scholarships for Latin America, scholarship No. E06D101359VE) and has been partially supported by the Generalitat Valenciana (GV/2011/039) and the University of Alicante (GRE09-27). Research on larval morphology received support from the SYNTHESYS Project http://www.synthesys.info/, which is financed by the European Community Research Infrastructure Action under the FP7 Integrating Activities Programme and the Polish Ministry of Science and Higher Education (grant no N N303 470838).

\section{References}

Al-Misned, F.A.M., Amoundi, M.A. \& Abou-Fannah, S.S.M. (2003) Development rate, mortality and growth rate of immature Chrysomya albiceps (Wiedemann) (Diptera: Calliphoridae) at constant temperatures. Journal of King Saud University 15, 49-58.

Bowden, J. (1997) Synthesiomyia nudiseta (Wulp) (Dipt., Muscidae) in Europe. Entomologists Monthly Magazine 133, 224.

Byrd, J.H. \& Castner, J.L. (2010) Insects of forensic importance. pp. 39-126 in Byrd, J.H. \& Castner, J.L. (Eds) Forensic Entomology: The Utility of Arthropods in Legal Investigations. Boca Raton, FL, USA, CRC Press.

Byrd, J.H. \& Tomberlin, J.K. (2010) Laboratory rearing of forensic insects. pp. 177-200 in Byrd, J.H. \& Castner, J.L. (Eds) Forensic Entomology: The Utility of Arthropods in Legal Investigations. Boca Raton, FL, USA, CRC Press.

Calderón-Arguedas, O., Troyo, A. \& Solano, M.E. (2005) Sucesión de larvas de muscoideos durante la degradación cadavérica en un bosque premontano húmedo tropical. Revista Biomédica 16, 79-85.

Carvalho, C.J.B. (2002) Muscidae (Diptera) of the Neotropical Region: Taxonomy. Curitiba, Brasil, Universidade Federal do Parana.

Couri, M.S. (2007) A key of the Afrotropical genera of Muscidae (Diptera). Revista Braziliera de Zoologia 24, 175-184.

Courtney, G.W., Sinclair, B.J. \& Meier, R. (2000) Morphology and terminology of Diptera larvae. pp. 75-163 in Papp, L. \& Darvas, B. (Eds) Contributions to a Manual of Palaearctic Diptera (with special reference to flies of economic importance), vol. 1. General and Applied Dipterology. Budapest, Hungary, Science Herald.

Disney, R.H.L. (2008) Natural history of the scuttle fly, Megaselia scalaris. Annual Review of Entomology 55, 39-60.

Donovan, S.E., Hall, M.J., Turner, B. \& Moncrieff, C.B. (2006) Larval growth rates of the blowfly, Calliphora vicina, over a range of temperature. Medical and Veterinary Entomology 20, 106-114.

Ebejer, M.J. \& Gatt, P. (1999) The species of Fanniidae and Muscidae of the Maltese Islands. Studia Dipterologica 6, 79-92.
El-Alfy, N.Z. (1994) Scanning electron microscopy of the eggshell of the fly Synthesiomyia nudiseta (Wulp). Qatar University Science Journal 14, 303-309.

Fessl, B., Sinclair, B.J. \& Kleindorfer, S. (2006) The life-cycle of Philornis downsi (Diptera: Muscidae) parasitizing Darwin's finches and its impact on nestlings survival. Parasitology 133, 739-747.

Goff, M.L. (2000) A Fly for the Prosecution: How Insect Evidence Helps Solve Crimes. Cambridge, MA, USA, Harvard University Press.

Gosselin, M. \& Braet, Y. (2008) Découverte de Chrysomya albiceps Wiedermann 1819 (Diptera, Calliphoridae), nouvelle espèce pour l'entomofaune nécrophage en Belgique et mise en evidence de son expansion à travers l'Europe. Bulletin de la Société royale belge d'Entomologie 144, 22-28.

Grassberger, M. \& Reiter, C. (2001) Effect of temperature on Lucilia sericata (Diptera: Calliphoridae) development with special reference to the isomegalen- and isomorphendiagram. Forensic Science International 120, 32-36.

Grassberger, M., Friedrich, E. \& Reiter, C. (2003) The blowfly Chrysomya albiceps (Wiedemann) (Diptera: Calliphoridae) as a new forensic indicator in Central Europe. International Journal of Legal Medicine 117, 75-81.

Greenberg, B. (1991) Flies as forensic indicators. Journal of Medical Entomology 28, 565-577.

Grzywacz, A., Pape, T. \& Szpila, K. (2012) Larval morphology of the lesser housefly, Fannia canicularis. Medical and Veterinary Entomology 26, 70-82.

Huchet, J.B. \& Greenberg, B. (2010) Flies, Mochicas and burial practices: a case study from Huaca de la Luna, Peru. Journal of Archaeological Science 37, 2846-2856.

Ishijima, H. (1967) Revision of the third stage larvae of synanthropic flies of Japan (Diptera: Anthomyiidae, Muscidae, Calliphoridae and Sarcophagidae). Japanese Journal of Sanitary Zoology 18, 47-100.

Jirón, L.F., Vargas, L.G. \& Vargas-Alvarado, E. (1983) Four muscoid flies (Sarcophagidae and Muscidae) associated with human cadavers in Costa Rica. Brenesia 21, 3-5.

Krüger, R.F., Ribeiro, P.B., Carvalho, C.J.B. \& Costa, P.R.P. (2002) Desenvolvimento de Synthesiomyia nudiseta (Diptera, Muscidae) em laboratorio. Iheringa, Série Zoologia 92, 25-30.

Kulshrestha, P., Satpathy, D.K. \& Dubey, B.P. (1997) Role of Synthesiomyia nudiseta (Muscidae) in forensic entomology. pp. 159-161 in Proceedings of the Third International Symposium on Advances in Legal Medicine, Osaka, Japan, Japanese Society of Legal Medicine.

Kumara, T.K., Abu Hassan, A., Che Salmah, M.R. \& Bhupinder, S. (2009) Larval growth of the muscid fly, Synthesiomyia nudiseta (Wulp), a fly of forensic importance, in the indoor fluctuating temperatures of Malaysia. Tropical Biomedicine 26, 200-205.

Lebrun, S. \& Mayer, G. (2011) First record of Synthesiomyia nudiseta (van der Wulp, 1883) (Diptera: Muscidae) from Italy. Dipterists Digest 18, 51-52.

Lee, H.L., Krishnasamy, M., Abdullah, A.G. \& Jeffery, J. (2004) Review of forensically important entomological specimens in the period of 1972-2002. Tropical Biomedicine 21, 69-75.

Lord, W., Adkins, T.R. \& Catts, E.P. (1992) The use of Synthesiomyia nudiseta (Van der Wulp) (Diptera, Muscidae) and Calliphora vicina (Robineau-Desvoidy) (Diptera, Calliphoridae) to estimate the time of death of a body buried under a house. Journal of Agricultural Entomology 94, 227-235. 
Marchenko, M.I. (2001) Medicolegal relevance of cadaver entomofauna for the determination of the time of death. Forensic Science International 120, 89-109.

Martínez-Sánchez, A. (2003). Biología de la comunidad de Dípteros necrófilos en ecosistemas del sureste de la península Ibérica. PhD thesis, Universidad de Alicante. Alicante, Spain.

Martínez-Sánchez, A., Marcos-García, M.A. \& Rojo, S. (2005) Biodiversidad de la comunidad de dípteros sarcosaprófagos en ambientes insulares del sudeste Ibérico (Diptera, Calliphoridae, Muscidae, Sarcophagidae). Nouvelle Revue d'Entomologie 22, 251-265.

Martínez-Sánchez, A., Smith, K.E., Rojo, S., Marcos-Gracía, M. A. \& Wall, R. (2007) Geographic origin affects larval competitive ability in European populations of the blow fly, Lucilia sericata. Entomologia Experimentalis et Applicata 6, 93-98.

Nazni, W.A., Nooraidah, H., Jeffery, J., Azahari, A.H., Mohd Noor, I., Sadiyah, I. \& Lee, H.L. (2007) Distribution and abundance of diurnal and nocturnal dipterous flies in the Federal Territory, Putrajaya. Tropical Biomedicine 24, 61-66.

Niederegger, S., Wartenberg, N., Spieß, R. \& Mall, G. (2011) Simple clearing technique as species determination tool in blowfly larvae. Forensic Science International 206, e96-98.

Omar, B., Marwi, M.A., Mansar, M.H., Rahman, M.S. \& Oothuman, P. (1994) Maggot of Synthesiomyia nudiseta (Wulp) (Diptera: Muscidae) as decomposer of corpses found indoor in Malaysia. Tropical Biomedicine 11, 145-148.

Pires de Alencar, A.P. \& Rios, A.C. (1992) Ultrastructure of the egg of Muscina stabulans and Synthesiomyia nudiseta (Diptera: Muscidae). Memórias do Instituto Oswaldo Cruz 87, 463-466.

Pont, A.C. (1986) Family Muscidae. pp. 1-345 in Soós, A. \& Papp, L. (Eds). Catalogue of Palaearctic Diptera. ScatophagidaeHypodermatidae, vol. 11. Amsterdam, Netherlands, Elsevier.

Pont, A.C. (1991) A review of the Faniidae and Muscidae (Diptera) of the Arabian Peninsula. Fauna of Saudi Arabia 12, 312-365.

Prado e Castro, C., Serrano, A., Martins da Silva, P. \& García, M. D. (2012) Carrion flies of forensic interest: a study of seasonal community composition and succession in Lisbon, Portugal. Medical and Veterinary Entomology, doi: 10.1111/j.13652915.2012.01031.x.

Rabinovich, J.E. (1970) Vital statistics of Synthesiomyia nudiseta (Diptera: Muscidae). Annals of the Entomological Society of America 63, 749-752.

Siddons, L.B. \& Roy, D.N. (1942) On the life history of Synthesiomyia nudiseta van der Wulp (Diptera, Muscidae), a myiasis-producing fly. Parasitology 34, 239-245.

Skidmore, P. (1985) The biology of the Muscidae of the world. Series Entomologica 29, 1-550.

Sukontason, K., Narongchai, P., Kanchai, C., Vichairat, K., Sribanditmongkol, P., Bhoopat, T., Kurahashi, H., Chockjamsai, M., Piangjai, S., Bunchu, N., Vongvivach, S.,
Samai, W., Chaiwong, T., Methanitikorn, R., Ngern-Klun, R., Sripakdee, D., Boonsriwong, W., Siriwattanarungsee, S., Srimuangwong, C., Hanterdsith, B., Chaiwan, K., Srisuwan, C., Upakut, S., Moopayak, K., Vogtsberger, R.C., Olson, J.K. \& Sukontason, K.L. (2007) Forensic entomology cases in Thailand: a review of cases from 2000 to 2006. Parasitology Research 101, 1417-1423.

Szpila, K. (2010) The First Instar of European Miltogramminae (Diptera: Sarcophagidae). Toruń, Poland., Wydawnictwo Naukowe UMK. 272.

Szpila, K. \& Pape, T. (2005) The first instar larva of Apodacra pulchra (Diptera: Sarcophagidae, Miltogramminae). Insect Systematics and Evolution 36, 293-300.

Szpila, K. \& Pape, T. (2008) Morphology of the first instar of the house fly Musca domestica (Diptera: Muscidae). Journal of Medical Entomology 45, 594-599.

Szpila, K. \& Villet, M.H. (2011) Morphology and identification of first instars of African blow flies (Diptera: Calliphoridae) commonly of forensic importance. Journal of Medical Entomology 48, 738-752.

Szpila, K., Matuszewski, S., Bajerlein, D. \& Konwerski, S. (2008a) Chrysomya albiceps (Wiedemann, 1819), a forensically important blowfly (Diptera: Calliphoridae) new for the Polish fauna. Polish Journal of Entomology 77, 351-355.

Szpila, K., Pape, T. \& Rusinek, A. (2008b) Morphology of the first instar larva of Calliphora vicina, Phormia regina, and Lucilia illustris (Diptera, Calliphoridae). Medical and Veterinary Entomology 22, 16-25.

Ubero-Pascal, N., Arnaldos, I. \& García, M.D. (2010a) Morphology comparison on inmature stages of Synthesiomyia nudiseta (Wulp, 1883) (Diptera: Muscidae) by light and scanning electron microscopy. p. 69 in Proceedings of the Eighth Meeting of the European Association for Forensic Entomology. European Association for Forensic Entomology, 8-11 September 2010, Murcia, Spain.

Ubero-Pascal, N., Arnaldos, I., López-Esclapez, R. \& García, M. D. (2010b) Microscopy and forensic entomology. pp. 15481556 in Méndez-Vilas, A. \& Díaz, J. (Eds) Microscopy: Science, Technology, Applications and Education. Badajoz, Spain, Formatex.

Uribe-M, N., Wolff, M. \& Carvalho, C.J.B. (2010) Synanthropy and ecological aspects of Muscidae (Diptera) in a tropical dry forest ecosystem in Colombia. Revista Brasileira de Entomologia 54, 462-470.

Velásquez, Y., Magaña, C., Martínez-Sánchez, A. \& Rojo, S. (2010) Diptera of forensic importance in the Iberian Peninsula: larval identification key. Medical and Veterinary Entomology 24, 293-308.

Verves, Y.G. (2004) Records of Chrysomya albiceps in the Ukraine. Medical and Veterinary Entomology 18, 308-310. 